\title{
Is Telecommunications Productivity Characterized by Steady State Conditions? Some Empirical Evidence for 13 OECD Countries
}

Claudia CURI \& Paolo MANCUSO $\left(^{*}\right)$

Facoltà di Ingegneria,University of Rome, Italy

\begin{abstract}
This paper studies the convergence process, or lack thereof, of Total Factor Productivity (TFP) for a panel of 13 OECD countries over the period 1979-2007, adding breadth and depth to the convergence debate in the telecommunications industry. TFP growth is examined through the Malmquist Index and decomposed in its main determinates. Absolute and conditional convergences are estimated. Fixed-effects estimates across countries convert the cross-section test of absolute convergence into a pooled test of conditional convergence. Our findings show a growth in TFP, mainly driven by technological process. It is boosted by an increase in production possibilities and lack of bias in input utilization. Inefficiency in scale is found. Convergence tests do not suggest support in favor of absolute convergence but do exhibit evidence of conditional convergence.

Key words: Total Factor Productivity (TFP), Data Envelopment Analysis (DEA), conditional b-convergence; Fixed Effects Model.
\end{abstract}

O ne of the main aspects of the new economy that needs to be revaluated is the contribution of information and communication technologies (ICT) industries to the potential growth of the economy. In fact, the knowledge-based economy relies on many assumptions regarding the increasing use of ICT and gets a new and different technological base. This leads to changes in the conditions of producing and distributing knowledge as well as in linking each other.

The breakdown of the worldwide ICT expenditures reveals that the telecommunications sector has the largest share (around 43\%), ahead of information technology services and software. More than half of the total

$\left.{ }^{*}\right)$ Acknowledgments: We would like to thank Dale Madsen (ITU) very much for supporting us in the data collection. We also thank two anonymous Referees for their helpful comments that considerably improve the paper. Lastly, Mrs Sophie Nigon for her support and patience during the entire revision process.

COMMUNICATIONS \& STRATEGIES, no. 74, $2^{\text {nd }}$ quarter 2009, p. 127. 
growth in ICT, during the last decade, is attributable to sales of telecommunications equipment and services (OECD, 2000). In fact, OECD telecommunications revenues are led by the access expansion as well as by the new telecommunications services. The size of wireless communication is still increasing even if prepaid customers, who tend to generate much less revenue than post paid wireless customers, account for a significant proportion. In 1999, one to four dollars of telecommunications service revenue was attributable to mobile communications. By 2001, the same ratio was just under one to three; in four countries, Belgium, Finland, Italy and Japan, $45 \%$ of all revenue was derived from wireless services (OECD, 2003). Therefore, the output measures based on the main lines in operation could underestimate the productivity evolution of countries characterized by the presence of relevant wireless market (JHA \& MAJUMDURA, 1999).

In general, outputs can be measured in physical and economic terms. For the economic measure, the deflated revenue is used and output is calculated by dividing revenue by an appropriate price index. The choice between the two measures depends upon the quality of data available and the complexity of the outputs being measured. In theory, if one had information on the revenue, price and quantity of each provided service; the physical output measure would produce the same result as the deflated revenue method. This is because the physical output measures would be based on the quantities of the different provided services, while the deflated revenue measures would be obtained by dividing the revenue of each service. Since the data on physical output are not available, the deflated revenue is typically used for the telecommunications industry (CHRISTENSEN et al., 2003). Thus starting from the data available from International Telecommunication Union database (ITU, 2008), we compute the Purchasing Power Parity (PPP) to deflate revenues. Our analysis is restricted to 13 OECD countries due to lack of information on the others.

Although there is a broad range of literature on the telecommunications productivity evolution (e.g. ANTONELLI, 1996; URI, 2002), few papers deal with the convergence analysis (MADDEN \& SAVAGE, 1999; KOSKI \& MAJADURAN, 2000; CALABRESE et al. 2002). The paper by Madden and Savage considers a large set of 74 countries, for a limited time period (19911995), and reveals the existence of a technological catch-up process in telecommunications. The paper by KOSKI \& MAJADURAN (2000) focuses on the convergence in telecommunications infrastructure development in 22 OECD countries over the period 1980-1995. It highlights the absence of absolute $\beta$-convergence in the efficiency of telecommunications infrastructure provision among OECD countries. Finally, the third paper 
carries out a convergence analysis for both Labour Productivity and Total Factor Productivity (TFP) among 13 OECD countries over the period 19791998. The paper states the presence of a weak absolute $\beta$-convergence process in Labour Productivity and the absence of such a process for TFP.

The main contribution of this paper is to accurately address the issue of total factor productivity convergence in telecommunications industries by testing the hypothesis of conditional b-convergence (Sala-i-Martin, 1996). In fact, the existence of absolute $\beta$-convergence is conditioned by the assumption that the only difference across telecommunications industries lies in their initial levels of capital. However, the differences among telecommunications industries may be ascribed to other factors connected to their own specific market features which lead to different steady states, avoiding any convergence process. In these cases, the neoclassical growth theory indicates that each industry growth rate depends on the distance which separates it from its own steady state and defines this concept as conditional b-convergence.

This study examines trends in telecommunications productivity and the issue of convergence among 13 OECD countries over the period 1979-2007 and three sub periods 1979-1988, 1988-1998, 1998-2007 ${ }^{1}$. We use Data Envelopment Analysis (DEA) to estimate TFP growth through the Malmquist Productivity Index (M) and its components: Technical Change and Technical Efficiency Change. They do not provide preliminary insights into the productivity catch-up. Therefore, a panel data model is used to analyze the conditional b-convergence. Our investigation suggests the existence of different steady states in productivity growth patterns among the 13 OECD countries which highlights the presence of conditional $b$-convergence.

The remainder of the paper is organized as follows: the following section examines and discusses the methodology to test the convergence hypothesis, the section after describes the data and some stylized facts which characterize the considered telecommunications industries over the period 1979-2007. Then, the empirical results are presented in terms of productivity evolution and convergence tests. The final section concludes.

\footnotetext{
1 The sub-periods appear to overlap since we work with chain indexes: each component of Malmquist Productivity Index is circular (see for details, FORSUND, 2002).
} 


\section{- Catch-Up, absolute and conditional convergence}

One of the fundamental pieces of evidence in the debate on international productivity convergence is that backward countries in a field can assimilate the technology knowledge from more advanced countries and increase their productivity more rapidly (GERSCHENKRON, 1962). According to this hypothesis, the presence of catch-up in an industry sector is positively correlated to the relative backwardness of a country in that sector. By using the traditional approach, the catching-up hypothesis can be tested (GOUYETTE AND PERELMAN, 1997) by the following relations:

$$
\begin{array}{ll}
r_{t}=\frac{T E_{\min , t}}{T E_{\text {max }, t}} & t=1, \ldots, T \\
\mu_{t}=\frac{\sum_{i=1}^{n} T E_{i, t}}{n} & t=1, \ldots, T
\end{array}
$$

where $T E_{\text {max }, t}$ and $T E_{\min , t}$ are the minimum and maximum efficiency levels, respectively, whereas TEi,t is merely the efficiency at a fixed time which could be estimated by the non parametric approach (CHARNES et al., 1978). A rise in $r_{t}$ as well in $\mu_{t}$ denote the existence of catching-up process. However, these indices establish the necessary but not the sufficient conditions for convergence (LICHTENBERG, 1994). Given that, absolute $\beta$ convergence and conditional $b$-convergence should be tested. The existence of absolute $\beta$-convergence relies on the key assumption that the only difference in productivity level across telecommunications industries lies in their initial levels of capital. According to the classical approach, it is tested by estimating the following regression model (BERNARD \& JONES, 1996):

$$
M_{i, t+1}=\alpha+\beta T E_{i, t}+\varepsilon_{i, t} \quad i=1, \ldots, n \quad t=1, \ldots, T-1
$$

where $M_{i, t+1}$ represents a measure of the total factor productivity change. A negative and significant value for $\beta$ provides the existence of absolute $\beta$ convergence, whereas $\beta>0$ supports non-convergence. However, telecommunications sectors may differ among countries due to different impacts of the specific market characteristics (MADDEN \& SAVAGE, 1999): they could lead to different steady states and hamper absolute productivity convergence. Moreover, telecommunications sectors also may converge towards their steady states at different speeds due to different variations in technical efficiency among countries. 
Given that and following BARRO \& SALA-I-MARTIN (1996), we estimate $\beta$ by adding some proxy variables that describe the steady state for each country and we test the hypothesis of conditional $b$-convergence. Thus, we estimate model described in [3], introducing structural variables $Z_{i, t}$ that hold constant the steady state of each industry sector. It is given by:

$$
M_{i, t+1}=\alpha+\beta T E_{i, t}+\varepsilon_{i, t} \quad i=1, \ldots, n \quad t=1, \ldots, T-1
$$

Since this work constitutes the first attempt to describe the steady states of telecommunications industries, the main difficulty is to identify the structural variables, also due to lack of data for such a long time period. We choose as structural variables: 1) the number of main lines per 100 inhabitants, 2) the capital labour ratio and 3) the existence of market liberalization.

More explicitly, the regression model specified by relation [4] can be written as follows:

$$
M_{i, t+1}=\alpha+b T E_{i, t}+\gamma Z_{i, t}+\varepsilon_{i, t} \quad i=1, \ldots, n \quad t=1, \ldots, T-1
$$

where $K_{i, t} / L_{i, t}$ is the capital labor ratio, $P_{i, t}$ is the number of main lines per 100 inhabitants and $S_{i, t}$ is the dummy variable which takes into account the existence of market liberalization ${ }^{2}$. While these data are the best currently available for the analyzed countries, the method could suffer from a shortcoming. According to ROS (1999), quoting KRIDEL et al. (1996), regulation may be endogenously determinated taking into account variables such as price cap or cost of service. However, LEVY \& SPILLER (1996), and GUITERREZ (2003) have distinguished the modelling of regulatory reforms between regulation governance and regulatory incentive in telecommunications. The first can be modelled through exogenous variables while the second by means of endogenous ones. Thus, since the variable $S_{i, t}$ is exogenously determined in the present paper, the impact of regulation governance is analyzed. Despite this shortcoming due to our assumption, this indicator provides a first empirical look at the importance of regulation in the context of conditional b-convergence in the telecommunications sector. Thus, a negative and significant coefficient $b$ suggests the existence of conditional productivity convergence among the 13 telecommunications

\footnotetext{
2 Setting the exact date of the market liberalization in the telecommunications is problematic since the structure of the market itself is, in fact, composed of many submarkets (local, trunk international line, wireless, etc). We assume that the presence of the liberalization process in just one of the sub-markets is enough to consider the existence of liberalization on the market (LEE, 2008).
} 
industries. In this case, the negative value of the coefficient of $T E_{i, t}$ does not mean that less productive telecommunications industries grow faster, but that they seem to reach some long-run level of productivity, which is captured by the additional three variables. Consequently, the productivity growth rate falls as the industry approaches this long-run level. A positive (negative) and significant value of $c$ implies a capital (labour) intensive nature of the services produced by the telecommunications industries (GOUYETTE \& PERELMAN, 1997). The variable main lines per 100 inhabitants, $P_{i, t}$, measures the capital utilization and consequently a negative value of the coefficient is attended. Market liberalization, $S_{i, t}$, should produce a positive impact on productivity evolution, increasing the capital utilization.

Two methods of estimation are used: the pooled data OLS estimation and the panel data estimation. The ongoing debate about the efficiency of the various estimation techniques points out that the main problem with the cross-sectional regressions is that the individual specific effects are ignored (e.g. EVANS, 1997; ISLAM, 1995). These effects can be correlated with the explanatory variables included in the convergence equation, creating estimation bias due to the omission of relevant variables. Given that, the main advantage deriving from the panel data approach is in the fact that one can take into account (and control) the unobserved country specific effects. More reliable estimates of the coefficients are then derived. This implies that in order to increase the steady state level, authorities must not only care about the rates of technical change, capital labour ratio, number of main lines and the fact that a market is liberalized or not, but also with every tangible and intangible factor that may be related to individual effects.

Thus, the regression model turns into the following equation:

$M_{i, t}=\alpha_{i}+b T E_{i, t}+c K_{i, t+1} / L_{i, t}+z P_{i, t}+v S_{i, t}+\varepsilon_{i, t} \quad i=1, \ldots, n \quad t=1, \ldots, \mathrm{T}$

where $\alpha_{i}$ is the time constant unobserved effect and $\varepsilon_{i, t+1}$ is the idiosyncratic error. Basically we have two alternative estimation methods: "fixed effects" estimation (FE) with within estimator and "random effects" estimation (RE) which is associated with GLS estimator. The former method assumes time constant unobserved effects which may represent the specific country characteristics (country heterogeneity) and are correlated with the explanatory variables. The latter assumes that these effects are captured in the stochastic error and are uncorrelated with the explanatory variables. Therefore, both methods require $\varepsilon_{i, t+1}$ being independent of regressors, but the random effects model has the additional requirements that the individual heterogeneity $\alpha i$ is independent of the regressors. If the additional 
requirement is met, then the random effects models and the effect of time invariant regressors are estimated without losing degrees of freedom.

Hence, model [6] turns into the following panel framework (respectively the fixed and random effects methods):

$$
\begin{gathered}
M_{i, t+1}=\alpha_{i}+b T E_{i, t}+c K_{i, t} / L_{i, t}+z P_{i, t}+v S_{i, t}+\varepsilon_{i, t+1} \\
i=1, \ldots, n \quad t=1, \ldots, T-1 \\
M_{i, t+1}=\alpha_{0, i}+b T E_{i, t}+c K_{i, t} / L_{i, t}+z P_{i, t}+v S_{i, t}+\varepsilon_{i, t+1} \\
i=1, \ldots, n \quad t=1, \ldots, T-1
\end{gathered}
$$

where $\alpha_{0, i}=\alpha_{0}+\alpha_{i}$. In the second model, we assume that $\alpha$ i. are the random errors which represent the heterogeneity specific to each country (constant over time), whereas in the first model we assumed them fixed.

Fixed effects model is particularly indicated when the regression analysis is limited to a precise set of individuals, firms or regions; random effect, instead, is an appropriate specification if we are drawing a certain number of individuals randomly from a large population of reference ${ }^{3}$. For this reason, since our data set consists in European regions, we decided to estimate the fixed effects model to check for convergence. However, to identify whether the unobservable variables are correlated with explanatory factors, we perform a HAUSMAN test (1978) comparing the fixed effects and random effects estimators. In this way we assure the choice of the best estimator in terms of efficiency and consistency. If the null is rejected, the random effects estimator is employed; otherwise, the fixed effects estimator is used (GUJARATI, 1995).

\section{Input and output data}

The first step in any productivity analysis is the definition of output measures. Clearly, it is possible to define it in physical terms: number of subscribers, total telephone traffics, minutes of tool uses, etc. A second way is through total revenue from telecommunications services, evenly divided

\footnotetext{
3 For more details on the discussion regarding the use of these two models for panel data we suggest to see specialised books on panel data (i.e. BALTAGI, 2001).
} 
for the number of employees or the number of lines (MADDEN \& SAVAGE, 1999). However, employing the exchange rate to express total revenues of the telecommunications industries in a common currency could be a source of bias in the analysis. In fact, the assumption underlying this procedure is that the exchange rate reflects exactly the relative prices of the telecommunications services provided in the different countries. The third way is to use deflated telecommunications revenues employing the Purchasing Power Parity (PPP). The choice of the method depends on the quality of data and the complexity of outputs to measure. The lack of physical quantity measures for the 13 telecommunications industries over so long a time horizon has restricted the choice between total revenue, expressed via the exchange rate (MADDEN \& SAVAGE, 1999; LIEN \& PENG, 2001), and volume measure obtained via the PPP (CHRISTENSEN et al., 2003).

In this work, the output is measured using the PPP-based volume. In turn, PPP is computed using the GEKS index number - by the names of GINI (1931), ELTETO \& KOVES (1964) and SZULC (1983) - and three price categories related to the telecommunication services. The GEKS index number satisfies both the properties of transitivity and base invariance and uses the Fisher binary indices. It is defined by the following relation:

$$
\text { GEKS } s_{i, t}^{h}=\sqrt[n]{\prod_{s=1}^{n} F_{s, t}^{h} \cdot F_{i, t}^{s}} \quad t=1, \ldots, T-1
$$

where $G E K S_{i, t}^{h}$, is the price index between country $h$ and $i, F_{s, t}^{h}$, denotes the Fisher price index for country $h$ with country $s$ as base at time $t$. These price categories are related to the following telecommunications services: residential telephone connection charges, cost of three minutes local calls and mobile connection charges in the years 1990 and 1991. In turn, they are normalized by using, respectively, the following weights: number of telephone main lines in operation, total national telephone traffic (minutes) and number of cellular mobile telephone subscribers. In Table 1, the PPP obtained by relation [9] and PPP TELCO are compared with those computed by OECD for Gross Domestic Product (GDP), Gross Capital Formation (GFC) and with the exchange rate in 1990 (OECD,1999).

It is important to note that the exchange rate should be not employed to compare the productivity of the 13 telecommunications industries since, in most of the cases, it underestimates the PPP TELCO. 
Table 1 - PPP for telecommunications (PPP TELCO), Gross Domestic Product (PPP GDP) and Capital Formation (PPP GFC) and Exchange Rate in 1990

\begin{tabular}{|l|l|l|l|l|}
\cline { 2 - 5 } \multicolumn{1}{c|}{} & \multicolumn{1}{c|}{$\begin{array}{c}\text { PPP } \\
\text { TELCO }\end{array}$} & \multicolumn{1}{c|}{$\begin{array}{c}\text { PPP } \\
\text { GDP० }\end{array}$} & $\begin{array}{c}\text { PPP } \\
\text { GFCF }\end{array}$ & \multicolumn{1}{|c|}{$\begin{array}{c}\text { EXCHANGE } \\
\text { RATE }^{\circ}\end{array}$} \\
\hline Australia (AUS) & 2.8 & 1.4 & 1.5 & 1.3 \\
\hline Belgium (BEL) & 66.5 & 39.5 & 46.6 & 33.4 \\
\hline Canada (CAN) & 3.4 & 1.3 & 1.3 & 1.2 \\
\hline Denmark (DNK) & 10.7 & 9.4 & 10.4 & 6.2 \\
\hline Finland (FIN) & 15.5 & 6.4 & 6.4 & 3.8 \\
\hline France (FRA) & 7.3 & 6.6 & 7.6 & 5.4 \\
\hline Italy (ITA) & 1797.6 & 1421 & 1768 & 1198.1 \\
\hline Japan (JAP) & 259.8 & 195.3 & 218.7 & 144.8 \\
\hline Netherlands (NLD) & 1.9 & 2.2 & 2.7 & 1.8 \\
\hline Norway (NOR) & 12.7 & 9.7 & 9.7 & 6.3 \\
\hline Sweden (SWE) & 4.2 & 9.3 & 10.3 & 5.9 \\
\hline United Kingdom (UK) & 1.7 & 0.6 & 0.8 & 0.6 \\
\hline United States (USA) & 1.0 & 1.0 & 1.0 & 1.0 \\
\hline
\end{tabular}

Source: OECD International Sectoral Database (ISDB), 1999

Therefore the measures of volume are obtained by dividing telecommunications revenues, expressed in each country's currency, by the corresponding PPP TELCO ${ }^{4}$. The evolution of the real output is characterized by a non linear trend (see Table 2).

Table 2 depicts the input and output variables as well as the market characteristics. It highlights differences in the structural characteristics of the 13 telecommunications industries. In fact, the evolution of the main lines per 100 inhabitants seems to indicate the absence of a homogenization process: starting from 1985, the spread between the minimum and the maximum shows slight changes. In the same way, the existence of different technologies or input markets could be reflected in the evolution of the capital labour ratio. All these variables are obtained from ITU (2008).

\footnotetext{
4 Before applying PPP, the total revenue, for each telecommunication industry has been expressed in real values, base year 1990, by means of consumer price index. The employed base period in the computation of the consumer price index, via Laysperes formula, reported by ITU data base is 1995 . Consequently the value of the price index, at 1990 price, has been obtained, for each country, dividing each price index, at 1995 price, by the value of the same index in 1990. Since the Laspeyres index does not satisfy the transitivity property, the weights system still remains fixed at 1995 one.
} 
Table 2 - Telecommunications Industry at glance, 1979-2007

\begin{tabular}{|c|c|c|c|c|}
\hline & $\begin{array}{l}1979 \\
1988 \\
\end{array}$ & $\begin{array}{l}1988 \\
1998 \\
\end{array}$ & $\begin{array}{l}1998 \\
2007 \\
\end{array}$ & $\begin{array}{l}1979 \\
2007 \\
\end{array}$ \\
\hline & \multicolumn{4}{|c|}{ Output } \\
\hline \multicolumn{5}{|l|}{ Volume (billions) } \\
\hline Mean & 14.15 & 18.7 & 30.21 & 18.7 \\
\hline Sqm & 28.94 & 39.57 & 60.54 & 39.57 \\
\hline Max & 124.52 & 197.48 & 260.43 & 197.48 \\
\hline Min & 0.35 & 0.51 & 1.1 & 0.51 \\
\hline & \multicolumn{4}{|c|}{ Inputs } \\
\hline \multicolumn{5}{|l|}{$\begin{array}{l}\text { Number of Main } \\
\text { Lines (milions) }\end{array}$} \\
\hline Mean & 19.12 & 26.37 & 30.17 & 26.37 \\
\hline Sqm & 29.08 & 39.58 & 46.76 & 39.58 \\
\hline Max & 127.09 & 179.85 & 192.51 & 179.85 \\
\hline Min & 1.15 & 2.02 & 1.74 & 2.02 \\
\hline \multicolumn{5}{|l|}{ Staff (milions) } \\
\hline Mean & 0.17 & 0.15 & 0.17 & 0.15 \\
\hline Sqm & 0.25 & 0.24 & 0.32 & 0.24 \\
\hline Max & 1.08 & 1.11 & 1.32 & 1.11 \\
\hline Min & 0.01 & 0.02 & 0.01 & 0.01 \\
\hline & \multicolumn{4}{|c|}{ Market Characteristics } \\
\hline \multicolumn{5}{|l|}{$\begin{array}{l}\text { Main Lines per } \\
100 \text { Inhabitants }\end{array}$} \\
\hline Mean & 40.41 & 52.5 & 54.49 & 52.50 \\
\hline Sqm & 9.3 & 7.89 & 8.15 & 7.89 \\
\hline Max & 66.23 & 72.10 & 72.11 & 72.10 \\
\hline Min & 21.62 & 35.48 & 32.97 & 35.48 \\
\hline \multicolumn{5}{|l|}{$\begin{array}{l}\text { Capital Labor } \\
\text { Ratio }\end{array}$} \\
\hline Mean & 120.67 & 177.93 & 203.50 & 177.93 \\
\hline Sqm & 37.84 & 50.31 & 88.44 & 50.31 \\
\hline Max & 221.88 & 358.76 & 526.21 & 358.76 \\
\hline Min & 50.89 & 81.67 & 96.45 & 81.67 \\
\hline \multicolumn{5}{|l|}{$\begin{array}{l}\text { Liberalizated } \\
\text { Markets }\end{array}$} \\
\hline & 16 & 62 & 117 & 195 \\
\hline
\end{tabular}

Source: ITU-World Telecommunication/ICT indicators (2008) 


\section{Empirical results}

\section{Measuring productivity and catch-up}

In order to measure the total factor productivity change we use the Malmquist Productivity Index (M) ${ }^{5}$ which is decomposed in Technical Efficiency Change (TEC) and Technical Change (TC) (FÄRE et al., 1992). Values of M, TEC, or TC greater (less) than one indicate productivity growth (decline), gains (losses) in efficiency, and technological progress (regress). In turn, Technical Efficiency Change depends on Pure Technical Efficiency Change (PEC) and a residual scale component, Scale Efficiency Change (SEC) which captures changes in the deviation between variable returns and constant returns to scale technology. Thus, if PEC > SEC then the major source of efficiency change (both increase and decrease) is improvement in pure technical efficiency, whereas if PEC < SEC the major source of efficiency is an improvement in scale efficiency. Moreover, Färe et al. (1996) propose to decompose TC into: Magnitude of Technical Change (MC) and Bias of the Technical Change (IBTC). The first component measures the evolution of the production possibility: $M C=1$ denotes a steady state while $M C>1(M C<1)$ highlights an increase (contraction) of the production possibility. IBTC measures the existence of bias in factor input utilisation. The source of bias can be investigated by comparing IBTC with the change in Capital Labor ratio (KLC). A value of IBTC $<1 \quad(>1)$ coupled with $K L C>1$ implies a capital-using bias (labour-using bias). Symmetrically, a value of IBTC $<1(>1)$ coupled with KLC $<1$ denotes a labour-using bias (capital-using bias).

Figure 1 shows the evolution of the geometric means of productivity change $\left(\mathrm{M}^{\circ}\right)^{6}$ and its main components, Technical Efficiency Change $\left(\mathrm{TEC}^{\circ}\right)$ and Technical Change $\left(\mathrm{TC}^{\circ}\right)^{7}$.

The analysis of the figure shows that the highest increase of TFP has been globally reached during the periods $1988-1998$ and 1998-2007: the TFP growth rate has been equal to $5.3 \%$ and $5.4 \%$, respectively, over these two periods.

\footnotetext{
5 See the Appendix for the mathematical formulation.

6 The apex ${ }^{\circ}$ denotes the geometric mean.

7 The analysis has been conducted by means of DEAP (COELLI, 1996)
} 
Figure 1 - Geometric means of TFP $\left(\mathrm{M}^{\circ}\right)$, Technical Efficiency Change $\left(\mathrm{TEC}^{\circ}\right)$ and Technical Change $\left(\mathrm{TC}^{\circ}\right)$

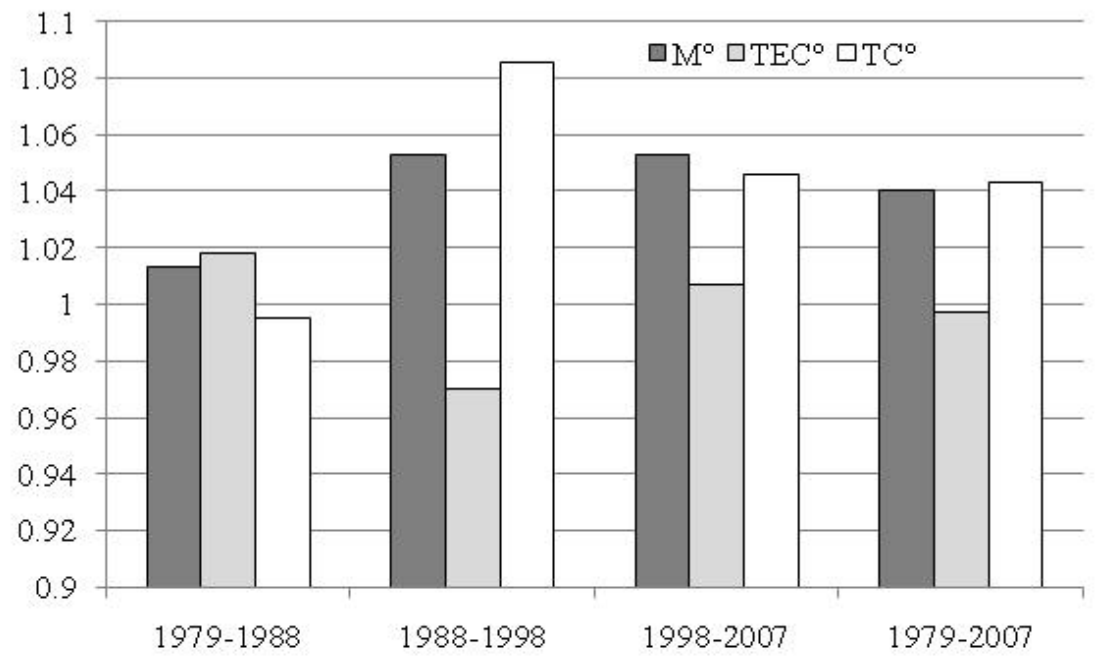

A possible explanation is related to the huge increase in diffusion of the mobile and internet services in that period: $33 \%$ of annual growth rates in the number of cellular mobile telephone subscribers and $37 \%$ in internet users (ITU, 2008). Considering the whole time horizon, TFP growth has been $4 \%$ per annum; it has been boosted by TC ( $4.3 \%$ per annum), and reduced by TEC (-0.2\% per annum).

Looking at the Technical Efficiency (TEC) and its components, both the Pure Technical Efficiency Change, $\mathrm{PEC}^{\circ}$, and Scale Efficiency Change, $\mathrm{SEC}^{\circ}$, show well defined patterns (Figure 2). In particular, SEC ${ }^{\circ}$ exhibits a cyclical pattern characterized by a declining rate during the period 19881998 (STARANCZAK et al., 1994), and an increasing rate from 1998 onward. As noticed above, the development of new telecommunication services can be considered the main determinant of such evolution. In fact, if on one hand the growth of mobile and internet has allowed a better exploitation of the scale economies, on the other the rapid acceleration of diffusion of these services could have been the main cause of an inefficient input-output configuration as well as an inefficient size of the operations. Lastly, the evolution of $\mathrm{IBCT}^{\circ}$ and $\mathrm{KLC}^{\circ}$ are depicted in Figure 3.

On average, the value of $\mathrm{KLC}^{\circ}$ is greater than one. Now, since $\mathrm{IBTC}^{\circ}$ is slightly greater than one we can conclude that the production process of our sample has not been affected by bias in the input utilisation. 
Figure 2 - Geometric mean of Technical Efficiency Change (TEC $\left.{ }^{\circ}\right)$, Pure Technical Efficiency Change $\left(\mathrm{PEC}^{\circ}\right)$ and Scale Efficiency Change (SEC $\left.{ }^{\circ}\right)$

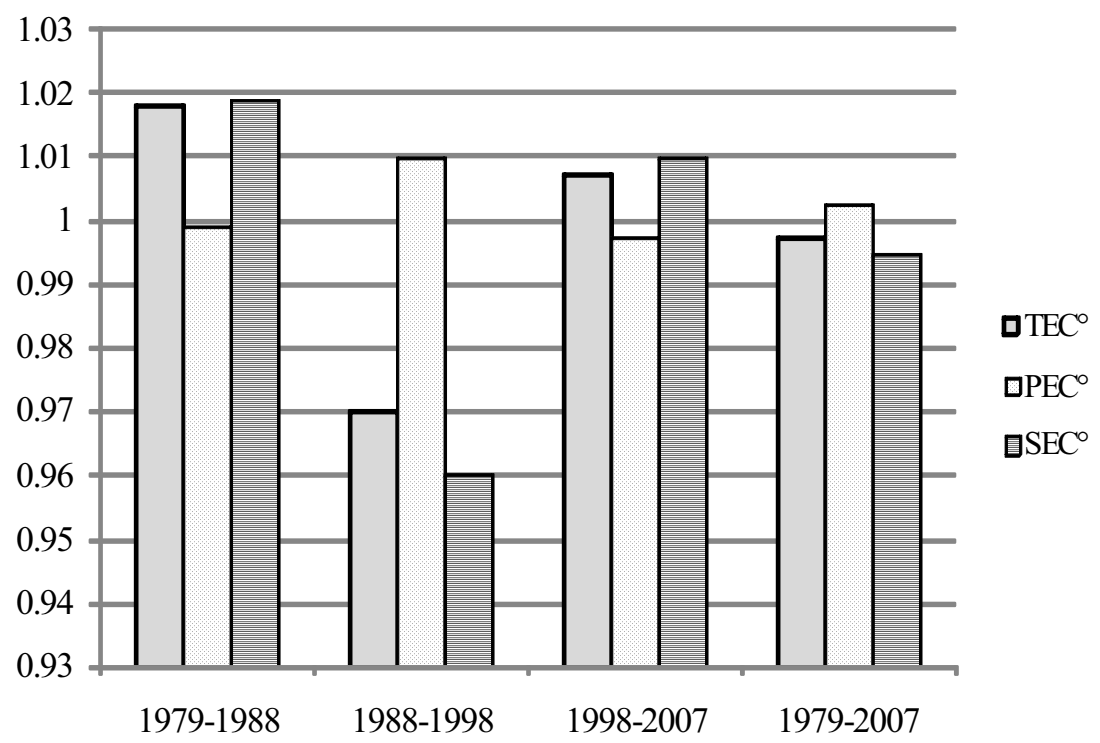

Figure 3 - Geometric means of Capital-Labour ratio $\left(\mathrm{KLC}^{\circ}\right)$, Magnitude of the Technical Change $\left(\mathrm{MC}^{\circ}\right)$ and Input Bias in Technical Change (IBTC $\left.{ }^{\circ}\right)$

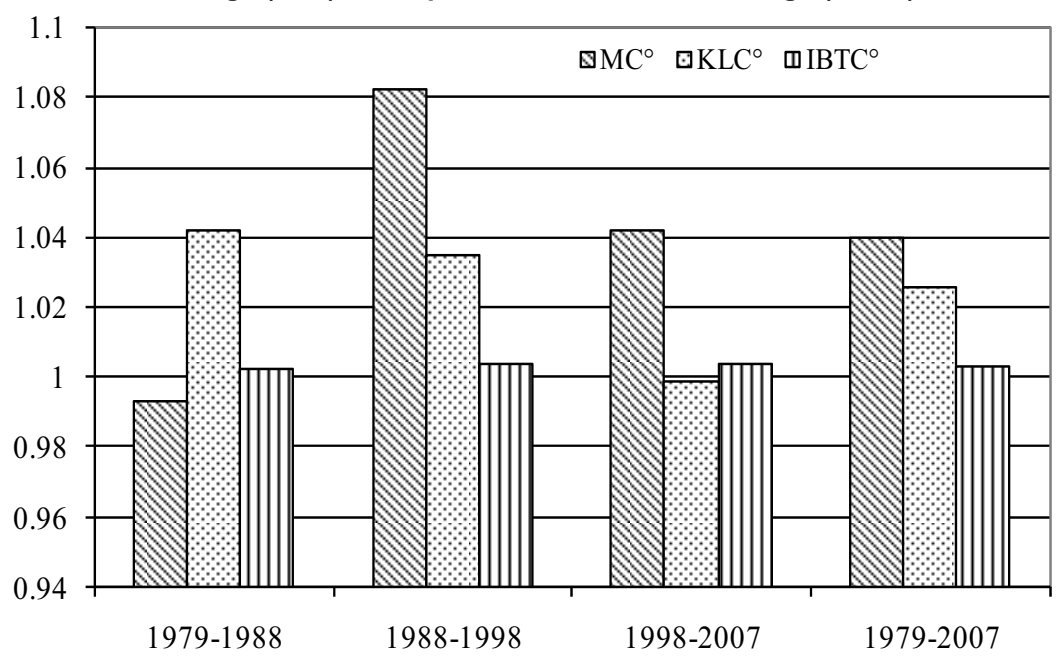

Furthermore, since the magnitude of the Technical Change, $\mathrm{MC}^{\circ}$, is greater than one, with the exception of the first period we can conclude that the production possibilities have steadily grown. Table 3 provides the values of TFP, $\mathrm{M}^{\circ}$, for the three sub-periods and the whole period. By comparing 
the three columns, it is evident that changes in ranking positions of the telecommunications industries in each period occur. This phenomenon could indicate, ex ante, the presence of a catch-up process. In fact, for each subperiod, telecommunications industries with lower level of productivity increase their ranking in the subsequent ones.

Table 3 - Geometric means of Total Factor Productivity Change ( $\overline{\mathrm{M}}$ )

\begin{tabular}{|l|l|l|l|l|l|l|l|}
\hline \multicolumn{2}{|c|}{$1979-1988$} & \multicolumn{2}{c|}{$1988-1998$} & \multicolumn{2}{c|}{$1998-2007$} & \multicolumn{2}{c|}{$1979-2007$} \\
\hline Country & M & Country & M & Country & M & Country & M \\
\hline ITA & 1.0985 & FIN & 1.0903 & GBR & 1.0774 & ITA & 1.0854 \\
\hline SWE & 1.0479 & ITA & 1.0813 & ITA & 1.0769 & SWE & 1.0634 \\
\hline NOR & 1.0467 & SWE & 1.0810 & FIN & 1.0767 & FIN & 1.0546 \\
\hline NLD & 1.0290 & JPN & 1.0670 & BEL & 1.0756 & DNK & 1.0451 \\
\hline DNK & 1.0180 & CAN & 1.0532 & DNK & 1.0683 & BEL & 1.0411 \\
\hline USA & 1.0118 & BEL & 1.0506 & SWE & 1.0597 & NOR & 1.0344 \\
\hline AUS & 1.0068 & NOR & 1.0501 & JPN & 1.0574 & GBR & 1.0341 \\
\hline GBR & 1.0044 & DNK & 1.0490 & FRA & 1.0482 & NLD & 1.0341 \\
\hline CAN & 0.9989 & AUS & 1.0461 & USA & 1.0421 & CAN & 1.0307 \\
\hline BEL & 0.9977 & NLD & 1.0401 & CAN & 1.0383 & AUS & 1.0296 \\
\hline FIN & 0.9955 & FRA & 1.0346 & AUS & 1.0343 & USA & 1.0267 \\
\hline FRA & 0.9820 & USA & 1.0264 & NLD & 1.0325 & JPN & 1.0224 \\
\hline JPN & 0.9427 & GBR & 1.0230 & NOR & 1.0053 & FRA & 1.0217 \\
\hline Geom.Mean & 1.0132 & & 1.0531 & & 1.0531 & & 1.0401 \\
\hline
\end{tabular}

\section{Measuring absolute and conditional convergence}

In this section, we investigate the presence of convergence process using the econometric models defined above. In Table 4 we report the mean of the minimum to the maximum efficiency level $\bar{r}$, and the mean of the average efficiency level, $\bar{\mu}$.

\begin{tabular}{|c|c|c|c|c|}
\hline & 1979-1988 & 1988-1998 & $1998-2007$ & $1979-2007$ \\
\hline $\bar{r}$ & 19.24 & 30.80 & 16.77 & 22.57 \\
\hline $\bar{\mu}$ & 57.01 & 53.98 & 41.25 & 50.86 \\
\hline
\end{tabular}

They suggest a lack of catch-up among the 13 OECD telecommunications industries in each sub-period. However, to formally 
assess the existence of absolute $\beta$-convergence in productivity levels, the OLS model defined by the relation [3] has been applied to the three subperiods (1979-1988, 1988-1998, 1998-2007) and the entire time horizon (1979-2007). We find that the $\beta$ coefficients are negative two sub-periods but are not statistically significant. A significant absolute $\beta$-convergence is found only the entire time horizon.

Thus, the next step is to test for conditional $b$-convergence by applying OLS on relation [5]. It can be seen from Table 6 that all $b$ coefficients are negative but not statistically significant, unless, for the entire period.

Table 5 - $\beta$-convergence (OLS results)

\begin{tabular}{|l|l|l|l|l|}
\hline \multicolumn{1}{|c|}{ Coefficient } & $1979-1988$ & $1988-1998$ & $1998-2007$ & $1979-2007$ \\
\hline$\alpha$ & 1.0196 & 1.0555 & 1.1132 & 1.0699 \\
$(72.45)^{\circ 00}$ & $(63.41)^{\circ 00}$ & $(30.48)^{\circ 00}$ & $(74.45)^{\circ \circ 0}$ \\
\hline$\beta$ & -0.0075 & 0.0011 & -0.1077 & -0.0449 \\
$(-0.34)$ & $(0.04)$ & $(-1.39)$ & $(-1.79)^{\circ \circ}$ \\
\hline$R^{2}$ & 0.0010 & $1.2 \mathrm{e}-5$ & 0.0166 & 0.0088 \\
\hline Number of obs. & 117 & 130 & 117 & 364 \\
\hline
\end{tabular}

t-statistic values are indicated in brackets. ${ }^{\circ},{ }^{\circ},{ }^{\circ}$ means statistically significant at $10 \%, 5 \%, 1 \%$ level, respectively.

Table 6 - Conditional b-convergence (OLS results)

\begin{tabular}{|l|l|l|l|l|}
\hline Coefficient & $1979-1988$ & $1988-1998$ & \multicolumn{1}{|c|}{$1998-2007$} & $1979-2007$ \\
\hline$\alpha$ & 1.2141 & 0.7917 & 0.5568 & 0.5866 \\
& $(8.35)^{\circ 00}$ & $(6.05)^{\circ 00}$ & $(2.90)^{\circ 00}$ & $(6.49)^{\circ 00}$ \\
\hline \multirow{2}{*}{$b$} & -0.0182 & -0.0065 & -0.1198 & -0.0472 \\
& $(-0.76)$ & $(-0.22)$ & $(-1.63)$ & $(-1.85)^{\circ \circ}$ \\
\hline \multirow{2}{*}{$c$} & -0.2005 & 0.1706 & 0.5669 & 0.3747 \\
& $(-1.54)$ & $(1.58)$ & $(4)^{\circ \circ 0}$ & $(4.91)^{\circ \circ 0}$ \\
\hline$z$ & 0.0005 & 0.0016 & -0.0001 & 0.0018 \\
& $(0.74)$ & $(0.157)$ & $(-0.06)$ & $(2.53)^{\circ 00}$ \\
\hline \multirow{2}{*}{$v$} & -0.0102 & 0.0107 & - & 0.0175 \\
\hline $\mathrm{R}^{2}$ & $(-0.58)$ & $(0.69)$ & - & $(1.17)$ \\
\hline Number of obs & 0.0348 & 0.0471 & 0.1400 & 0.0906 \\
\hline
\end{tabular}

t-statistic values are indicated in brackets. ${ }^{\circ},{ }^{\circ},{ }^{\circ}$ means statistically significant at $10 \%, 5 \%, 1 \%$ level, respectively.

Differently, testing for the conditional convergence hypothesis by the panel data approach suggests support for of conditional b-convergence over the periods 1979-1988, 1998-2007 and the entire period, as shown in Table 7. 
The speed of convergence tends to be much larger than those obtained by OLS, as found by BARRO \& SALA-I-MARTIN (1995). Moreover, it is worth noting that an acceleration of the convergence process occurs over time (values of b estimates vary of -0.2276 to -1.1695 ). The higher speed of convergence indicates that the European telecommunications sectors are getting closer to their steady states. Therefore, the differences in observed levels of total factor productivity are arising from differences in the steady state levels. The value of $R^{2}$-within is relative high compared to the $R^{2}$ between. This highlights that the bulk of the differences in TFP changes come from differences in technical change and market characteristics for individual sectors.

\begin{tabular}{|c|c|c|c|c|}
\hline Coefficient & 1979-1988 & 1988-1998 & $1998-2007$ & $1979-2007$ \\
\hline$\alpha$ & \begin{tabular}{|l|}
1.2340 \\
$(8.77)^{\circ 0 \circ}$
\end{tabular} & $\begin{array}{l}0.4144 \\
(1.74)^{\circ}\end{array}$ & $\begin{array}{l}1.02 \\
(3.33)^{\circ 00}\end{array}$ & $\begin{array}{l}0.6045 \\
(5.71)^{\circ 0 \circ}\end{array}$ \\
\hline$b$ & $\begin{array}{l}-0.2276 \\
(-3.02)^{\circ \circ \circ}\end{array}$ & $\begin{array}{l}0.0236 \\
(0.12)\end{array}$ & $\begin{array}{l}-1.1695 \\
(-5.36)^{\circ \circ \circ}\end{array}$ & $\begin{array}{l}-0.2389 \\
(-4.10)^{\circ \circ \circ}\end{array}$ \\
\hline$c$ & $\begin{array}{l}-0.2336 \\
(-1.95)^{\circ}\end{array}$ & $\begin{array}{l}0.2354 \\
(2.02)^{\circ \circ}\end{array}$ & $\begin{array}{l}0.4613 \\
(3.37)^{\circ 00}\end{array}$ & \begin{tabular}{|l|}
0.4001 \\
$(5.32)^{\circ 00}$
\end{tabular} \\
\hline$z$ & \begin{tabular}{|l|}
0.0038 \\
$(2.50)^{\circ \circ}$
\end{tabular} & $\begin{array}{l}0.0071 \\
(2.81)^{\circ \circ 0}\end{array}$ & $\begin{array}{l}0.0012 \\
(0.30)\end{array}$ & $\begin{array}{l}0.0031 \\
(3.03)^{\circ 00}\end{array}$ \\
\hline$v$ & $\begin{array}{l}-0.0019 \\
(-0.09)\end{array}$ & $\begin{array}{l}0.0198 \\
(0.77)\end{array}$ & & $\begin{array}{l}-0.0079 \\
(-0.44)\end{array}$ \\
\hline $\mathrm{R}^{2}$-within & 0.1480 & 0.1095 & 0.3154 & 0.1544 \\
\hline $\mathrm{R}^{2}$-between & 0.0000 & 0.0274 & 0.0226 & 0.0741 \\
\hline Number of obs. & 117 & 130 & 117 & 364 \\
\hline
\end{tabular}

t-statistic values are indicated in brackets. ${ }^{\circ},{ }^{\circ 0},{ }^{\circ \circ}$ means statistically significant at $10 \%, 5 \%, 1 \%$ level, respectively.

As far as the other variables are concerned, capital labour ratio has a notable positive impact on TFP and it is significant for all the periods (see Table 7). Thus differences in the capital labour ratio seem be one of the causes of diversity in the productivity patterns. In turn, the absence of homogeneity in the capital labour ratio can be explained by the absence of a homogeneous diffusion process in the new telecommunications services, such as the mobile and the internet ones. The low values of the coefficients $z$ indicate that the number of main lines per 100 inhabitants has a negligible, but positive, impact. However, it is statistically significant, in the same periods when the conditional convergence occurs. The low value of $v$ indicates a negligible impact on TFP evolution. However, we find a more evident impact between 1988-1998 denoting a positive correlation between 
TFP movements and the market liberalization process. Estimates provided by the model chosen by the Hausman test, are reported in Table 8.

Table 8 - Conditional b-convergence: panel data results (Fixed Effects and Random Effects model)

\begin{tabular}{|c|c|c|c|c|}
\hline Coefficient & $1979-1988^{(*)}$ & 1988-1998 & $1998-2007^{(*)}$ & $1979-2007^{(*)}$ \\
\hline$\alpha$ & $\begin{array}{l}1.2013 \\
(8.76)^{\circ \circ \circ}\end{array}$ & $\begin{array}{l}0.4144 \\
(1.74)^{\circ} \\
\end{array}$ & \begin{tabular}{|l|}
0.5568 \\
$(2.90)^{\circ \circ \circ}$ \\
\end{tabular} & $\begin{array}{l}0.5758 \\
(6.31)^{\circ \circ \circ} \\
\end{array}$ \\
\hline$b$ & $\begin{array}{l}-0.0650 \\
(-1.64)\end{array}$ & $\begin{array}{l}0.0236 \\
(0.12)\end{array}$ & $\begin{array}{l}-0.1198 \\
(-1.63) \\
\end{array}$ & $\begin{array}{l}-0.5733 \\
(-2.08)^{\circ \circ}\end{array}$ \\
\hline c & $\begin{array}{l}-0.2068 \\
(-1.72)^{\circ}\end{array}$ & $\begin{array}{l}0.2354 \\
(2.02)^{\circ \circ}\end{array}$ & $\begin{array}{l}0.5700 \\
(4)^{\circ 00}\end{array}$ & $\begin{array}{l}0.3797 \\
(4.99)^{\circ 00}\end{array}$ \\
\hline$z$ & $\begin{array}{l}0.0016 \\
(1.51)\end{array}$ & $\begin{array}{l}0.0071 \\
(2.81)^{\circ 00}\end{array}$ & $\begin{array}{l}-0.0001 \\
(-0.06)\end{array}$ & $\begin{array}{l}0.0021 \\
(2.71)^{\circ \circ 0}\end{array}$ \\
\hline$v$ & $\begin{array}{l}0.0101 \\
(0.54)\end{array}$ & $\begin{array}{l}0.0198 \\
(0.77)\end{array}$ & & $\begin{array}{l}0.0161 \\
(1.05)\end{array}$ \\
\hline $\mathrm{R}^{2}$-within & 0.1174 & 0.1095 & 0.1555 & 0.1292 \\
\hline $\mathrm{R}^{2}$-between & 0.0006 & 0.0274 & 0.0236 & 0.1134 \\
\hline Hausman & $17.41^{000}$ & 8.41 & $27.40^{\circ 00}$ & $27.86^{\circ 00}$ \\
\hline Number of obs. & 117 & 130 & 117 & 364 \\
\hline
\end{tabular}

(*) Random Effects model.

t-statistic vales are indicated in brackets. ${ }^{\circ},{ }^{\circ},{ }^{\circ 0}$ means statistically significant at $10 \%, 5 \%, 1 \%$ level, respectively.

It appears that the first and last periods as well the entire period are better estimated via random effects models. This implies that the individual effects are found to be uncorrelated with the explaining variables and/or there are some other omitted variables not accounted, measurement errors, etc. However, they support the results previously found due to negative estimates of $b$.

These results compose an economic scenario characterized by a high persistence of each telecommunications sector in the relative position. Explaining the absence of absolute TFP convergence is a difficult task due to the lack of additional explicative variables which should be included as they clearly supported the results obtained through the fixed and the random models. The absence of a homogeneous diffusion process in the new telecommunications services, affecting the capital labour ratio, could be one of the causes of the differences in productivity patterns among telecommunications industries. Moreover, the lack of a large degree of regulatory harmonization due to different regulatory contexts among the countries can contribute to hamper this phenomenon. 


\section{- Conclusion}

This analysis measures the TFP growth and then examines the existence of the convergence process in the telecommunications industry among 13 OECD countries. The open issue of conditional $b$-convergence is addressed due to the lack of empirical evidence of catch up convergence in the current literature. The empirical results show an average growth rate of TFP of $4.0 \%$ a year over the period 1979-2007. Noticeably, its evolution has not been constant over time: in particular, the diffusion of the mobile and internet services has been one of the main causes of the increase in TFP growth during 1988-2007. On average, this growth has been led by technological progress due to a rate of technical change $(4.3 \%)$ greater than the rate of efficiency change $(-0.2 \%)$. The source of inefficiency has relied on the rapid expansion of the new telecommunication services during the period 19881998 which have not allowed reaching the optimal size of operations (scale inefficiencies). As far as the innovation process is concerned, we show as the 13 telecommunications industries have been characterized by both a production process without bias in the labour capital employment and an increase in their production possibilities.

The second part of the analysis is focussed on the convergence process. First, we note that productivity catch-up has not occurred among the 13 telecommunications industries analyzed and that the traditional regression model has narrowed the presence of the absolute $\beta$-convergence and conditional b-convergence over the period 1979-2007. However, aware of the bias incorporated in the OLS estimates in the context of convergence, the conditional $b$-convergence has been investigated by a panel data approach. The steady states have been described by structural variables aimed to capture the essential (at macro level) characteristics of telecommunications market and parameters are estimated by fixed effects model (following BALTAGI, 2001). The findings support the presence of conditional $b$-convergence for the sub-periods 1979-1988 and 1998-2007 as well as for 1979-2007. Differences in capital labour ratio seem be one of the causes of diversity in the productivity patterns. However, more research is needed to confirm the sources of lack of convergence. This work could be extended towards a more detailed analysis when additional variables that describe the market in terms of degree of internalization, market organisation and the type of regulation are available for a long enough time span. 


\section{Appendix: Malmquist Productivity Index and its decompositions}

In this paper, the measure of Total Factor Productivity (TFP) in telecommunications industry is obtained using the Malmquist input-oriented productivity index which is based on the measure of the technical efficiency. To compute Malmquist Productivity Index for each telecommunications industry, or Decision Making Unit (DMU), three Data Envelopment Analysis problems have to be solved. The first one, based on the assumption of constant return to scale, is given by:

$$
\begin{aligned}
T E_{i, t}=\left[D_{i, t}\left(\mathrm{y}_{i, t}, \mathrm{x}_{i, t}\right)\right]^{-1}=\min _{\theta, \lambda} \theta & \\
\text { s.t. } \quad \mathrm{y}_{i, t} & \leq Y_{t} \lambda \quad \quad i=1, \ldots, n \quad t=1, \ldots, T \\
\theta \mathrm{x}_{\mathrm{i}, \mathrm{t}} & \geq X_{t} \lambda \\
\lambda & \geq 0
\end{aligned}
$$

where $D_{i, t}\left(y_{i, t}, x_{i, t}\right) \quad(i=1,2, \ldots n ; t=1,2, \ldots T)$ is Debreu's distance function (DEBREU, 1951), $Y_{t}$ is a sxn matrix of observed output, $X_{t}$ is a rxn matrix of observed input and $\lambda$ represent a $n \times 1$ vector of weights which allow to obtain a convex combinations of inputs and outputs. The remaining two models are computed to take into account the presence of increasing or decreasing returns to scale and obtained by imposing $\lambda \lambda^{\prime}=1$ and $\lambda \lambda^{\prime} \leq 1$ in the minimization problem [A1], respectively.

The three linear programming models allow writing Malmquist input-oriented productivity index (Färe et al. 1992) as follows:

$$
M_{i, t+1}=\frac{D_{i, t+1}\left(\mathrm{x}_{i, t+1}, \mathrm{y}_{i, t+1}\right)}{D_{i, t}\left(\mathrm{x}_{i, t}, \mathrm{y}_{i, t}\right)}\left(\frac{D_{i, t}\left(\mathrm{x}_{i, t+1}, \mathrm{y}_{i, t+1}\right)}{D_{i, t}\left(\mathrm{x}_{i, t}, \mathrm{y}_{i, t}\right)} \times \frac{D_{i, t+1}\left(\mathrm{x}_{i, t+1}, \mathrm{y}_{i, t+1}\right)}{D_{t+1}\left(\mathrm{x}_{i, t}, \mathrm{y}_{i, t}\right)}\right)^{0.5}=T E G_{, t+1} \times T G_{i, t+1}
$$

where $T E C_{i, t+1}$ and $T C_{i, t+1}$ represents the Technical Efficiency and Technical Change, respectively. Values of $M_{i, t+1}, T E C_{i, t+1}$, or $T C_{i, t+1}$ greater (less) than one indicate productivity growth (decline), gains for the DMU $i(i=1,2, \ldots, n)$ between period $t$ and $t+1$.

Following FÄRE et al. (1994), relation [A2] can take the form:

$$
M_{i, t+1}=\left(P E C_{i, t+1} \times S E C_{i, t+1}\right) \times\left(M C_{i, t+1} \times I B T C_{i, t+1}\right) \quad i=1, \ldots, n \quad t=1, \ldots, T \quad \text { [A3] }
$$

where PECi,t+1 is the Pure Technical Efficiency Change, SECi,t+1 is the Scale Efficiency Change, $M C i, t+1$, is the Magnitude of the Technical Change and IBTCi,t+1 is the bias of Technical Change. The nature of input technical bias can be assessed comparing the value of IBTCi,t+1 to the evolution of the capital-labour ratio (FÄRE et al.,1996):

$$
K L C_{i, t+1}=\frac{K_{i, t+1} / L_{i, t+1}}{K_{i, t} / L_{i, t}} \quad i=1, \ldots, n \quad t=1, \ldots, T
$$

A value of $I B T C_{i, t+1}<1(>1)$ coupled with $K L C_{i, t+1}>1$ implies a capital-using bias (labour-using bias) between periods $t$ and $t+1$. Symmetrically, a value of $I B T C_{i, t+1}<1$ $(>1)$. 


\section{References}

ANTONELLI, C. (1996): "The network of networks: localized technological change in telecommunications and productivity growth", Information Economics and Policy, 8, 317-355.

BALTAGI B.H. (2001): Econometric analysis of panel data, $2^{\text {nd }}$ edition Chichester, UK: Wiley.

BARRO, R.J. \& SALA-i-MARTIN, X.X.:

- (1991): "Convergence Across States and Regions", in Brookings Papers on Economic Activity, 1, 107-182.

- (1995): Economic Growth, McGraw Hill, New York.

BERNARD, A. \& JONES, C. (1996): "Comparing Apples to Oranges: Productivity Convergence and Measurement Across Industries and Countries", American Economic Review, 86, 1216-1238.

CALABRESE, A., CAMPISI D. \& MANCUSO P. (2002): "Productivity Change in the Telecommunication Industry of 13 OECD countries", International Journal of Business and Economics, 11, 209-223.

CHARNES, A., COOPER, W.W. \& RHODES, E. (1978): "Measuring the efficiency of decision making units", European Journal of Operational Research, 2, 429-444.

CHRISTENSEN, L.R., SCHOECH, E.P. \& MEITZEN, M.E. (2003): "Telecommunications Productivity", in G. MADDEN (Ed.) Traditional Telecommunication Networks, Edward Elgar, Cheltenham, UK.

COELLI, T. (1996): "A guide to DEAP version 2.1 A Data Envelopment Analysis (computer) ProgrSam", CEPA Working Paper 96/08, Armidale, University of New England.

DEBREU, G. (1951): "The Coefficient of Resource Utilization", Econometrica, 19, 273-292.

ELTETO, O. \& KOVES, P. (1964): "On Index Computation Problem of International Comparisons", Stantiszkai Smetze, 42, 507-518.

EVANS, P. (1997): "How Fast Do Economies Converge?", Review of Economics and Statistics 36, 219-225.

FÄRE, R., GROSSKOPF, G., LINDGREN, B. \& ROOS, P. (1992): "Productivity changes in Swedish pharmacies 1980-1989: A non parametric Malmquist approach", The Journal of Productivity Analysis, 3, 80-101.

FÄRE R., GROSSKOPF, S., NORRIS, M. \& ZANG Z. (1994): "Productivity Growth, Technical Progress and Efficiency Change in Industrialized Countries", American Economic Review 84, 66-83. 
FÄRE, R., GRIFELL-TATJÉ E., GROSSKOPF S. \& LOVELL C.A.K. (1996): "Biased Technical Change and the Malmquist Productivity Index", The Scandinavian Journal of Economics, 99, 119-127.

FØRSUND, F.R. (2002): "On the circularity of the Malmquist Productivity Index", ICER working papers.

GERSCHENKRON, A. (1962): Economic Backwardness in Historical Perspective: A Book of Essays, Belknap Press of Harvard University Press.

GINI, C. (1931): "On the Circular test of index number", Metron, 9, 3-24.

GOUYETTE, C. \& PERELMAN S. (1997): "Productivity Convergence in OECD Service Industries", Structural Change and Economics Dynamics, 8, 364-380.

GUITIERREZ L.H. (2003): "The effect of endogenous regulation on telecommunications expansion and efficiency in Latin America", Journal of Regulatory Economics, 23, 257-286.

GUJARATI, D.N. (1995): Basic Econometrics, $3^{\text {rd }}$ edition, McGraw-Hill, Inc., USA.

HAUSMAN, J.A. (1978): "Specification tests in econometrics", Econometrica, 46, 1251-1271.

ISLAM N. (1995): "Growth empirics: A panel data approach", Quarterly Journal of Economics, 4, 1127-1170.

ITU (2008): World Telecommunication/ICT Indicators Database 2008, (12 ${ }^{\text {th }}$ edition).

KOSKI, H.A. \& MAJUMDAR, S.K. (2000): "Convergence in Telecommunications Infrastructure Development in OECD Countries", Information Economics and Policy, $12,111-131$.

KRIDEL, D., SAPPINGTON, D.E.M. \& WEISMAN, D.L. (1996): "The Effects of incentive regulation in the Telecommunications Industry: a Survey", Journal of Regulatory Economics, 9, 269-306.

JHA, R. \& MAJUMDURA, S.K. (1999): "A Matter of Connections: OECD Telecommunications Sector Productivity and the Role of Cellular Technology Diffusion", Information Economics and Policy, 11, 243-269.

LEE, S. (2008): "Market liberalization and ownership status of incumbent telecom enterprises: global evidence from the telecom sector", Economics Bulletin, 12, 1-10.

LEVY, B. \& SPILLER, P. (1996): Regulations, Institutions, and Commitment: Comparative Studies of telecommunications, Cambridge University Press.

LICHTENBERG, F.R. (1994): "Testing the Convergence Hypothesis", The Review of Economics and Statistics, 76, 576-579.

LIEN, D. \& PENG, Y. (2001): "Competition and Production Efficiency Telecommunications in OECD", Information Economics and Policy, 13, 51-76. 
MADDEN, G. \& SAVAGE, G.M. (1999): "Telecommunication Productivity, Catch-up and Innovation", Telecommunications Policy, 23, 65-81.

OECD:

- (1999): International Sectoral Data Base, ISDB 98, OECD Publications, Paris.

- (2000): OECD Information Technology Outlook 2000, OECD Publications, Paris.

- (2003): OECD Communication Outlook 2003, OECD Publications, Paris.

ROS, A.J. (1999): "Does ownership or competition market? The effects of telecommunications reform on network expansion and efficiency", Journal of Regulatory Economics, 15, 65-92.

SALA-i-MARTIN, X.X. (1996): "The Classical Approach to Convergence Analysis", Economic Journal, 106, 1019-1036.

SZULC, B. (1983): "Linking price index number", in DIEWERT W.E. \& MONTMARQUETTE C. (Eds): Price level measurement, Minister of Supply, Canada, Ottawa.

STARANCZAK, M.Z., SEPULVEDA, E.R., DILWORTH, P.A. \& SHAIKH, S.A. (1994): "Industry Structure, Productivity and International Competitiveness: The Case of Telecommunications", Information Economics and Policy, 6, 121-142.

URI, N.D. (2002): "The Measurement of the Change in Productivity in Telecommunications", Telecommunication Systems, 20, 177-194. 